\title{
WASPADA COVID-19: PEMBAGIAN HANDSANITIZER DAN MASKER KAIN GRATIS KEPADA PENGEMUDI OJEK
}

\author{
Alvi Kusuma Wardani ${ }^{11}$, Nurul Qiyaam ${ }^{1)}$, Cyntiya Rahmawati2), Baiq Leny Nopitasarii1), Baiq Nurbaety²), \\ Dzun Haryadi Ittiqo'), Abdul Rahman Wahid²) \\ 1) Program Studi S1 Farmasi, Fakultas IImu Kesehatan, Universitas Muhammadiyah Mataram
2) Program Studi D3 Farmasi, Fakultas IImu Kesehatan, Universitas Muhammadiyah Mataram \\ Corresponding author :Alvi Kusuma Wardani \\ E-mail :alvikusuma99@gmail.com
}

Diterima 13 Agustus 2020, Direvisi 28 Oktober 2020, Disetujui 29 Oktober 2020

\begin{abstract}
ABSTRAK
Coronavirus Disease 2019 (Covid-19) merupakan penyakit yang disebabkan oleh Severe Acute Respiratory Syndrome Coronavirus 2 (Sars-Cov-2). Virus ini menyebar melalui percikan (droplets) dari saluran pernapasan yang dikeluarkan saat sedang batuk atau bersin.Salah satu faktor risiko yang menyebabkan penularan covid-19 pada tukang ojek baik ojek online maupun offline adalah adanya kontak dalam jarak deka tantara penumpang yang mungkin positif covid-19 dengan pengemudi ojek itu sendiri. Sebagian besar pengemudi ojek yang tidak melengkapi dirinya dengan alat pelindung diri (APD) sebagai salah satu langkah pencegahan penularan covid-19. Minimnya pengetahuan dan kesadaran tentang bahaya covid-19 serta kurangnya pemasukan tiap harinya membuat para pengemudi ojek tidak menggunakan APD seperti masker. Kegiatan ini membagikan handsanitizer dan masker kain kepada pengemudi ojek sebagai upaya pencegahan dan pemutusan rantai penularan Covid-19.
\end{abstract}

Kata kunci:covid-19; masker; handsanitizer; pengemudi ojek.

\begin{abstract}
Coronavirus Disease 2019 (Covid-19) is a disease caused by Severe Acute Respiratory Syndrome Coronavirus 2 (Sars-Cov-2). This virus spreads through droplets from the respiratory tract that are released while coughing or sneezing. One of the risk factors that cause covid-19 transmission to ojek drivers both online and offline is that there is contact within the distance between passengers who might be positive with the ojek drivers themselves. Most of the ojek drivers who do not equip themselves with personal protective equipment (PPE) as a preventive measure for covid-19 transmission. The lack of knowledge and awareness about the dangers of covid-19 and the lack of daily income makes ojek drivers do not use PPE like a mask. This activity distributed handsanitizers and masks to ojek drivers as an effort to prevent and break the covid-19 transmission chain.
\end{abstract}

Keywords: covid-19; mask; handsanitizer; ojek driver.

\section{PENDAHULUAN}

Pandemi virus corona tahun 20192020 telah menyebar ke Indonesia tepat tanggal 2 Maret 2020 sebanyak 2 kasus, dan terus bertambah sampai pada tanggal 14 Maret 2020 jumlah kasus sebanyak 96 orang dengan 5 meninggal (Kementerian Kesehatan Republik Indonesia, 2020). Hingga 28 April 2020, telah terkonfirmasi 9.511 kasus positif Covid-19 dengan 1.254 kasus sembuh dan 773 kasus meninggal (kawalcovid19.id).

Coronavirus Disease 2019 (Covid-19) merupakan penyakit yang disebabkan oleh Severe Acute Respiratory Syndrome Coronavirus 2 (Sars-Cov-2). Virus ini menyebar melalui percikan (droplets) dari saluran pernapasan yang dikeluarkan saat sedang batuk atau bersin. Penderita covid-19 dapat mengalami demam, batuk kering, dan kesulitan bernapas. Sakit tenggorokan, pilek, atau bersin-bersin lebih jarang ditemukan. Pada penderita yang paling rentan, penyakit ini dapat berujung pada pneumonia dan kegagalan multi organ (WHO, 2019).

Coronavirus Disease 2019 (COVID-19) adalah penyakit jenis baru yang belum pernah diidentifikasi sebelumnya pada manusia. Virus penyebab COVID-19 ini dinamakan Sars-CoV2 . COVID-19 adalah penyakit baru, dimana penelitian terkait penyakit ini masih sedikit. Diperlukan informasi yang berbasis bukti (evidence base) tentang perawatan, pengobatan, maupun informasi lainnya terkait penyakit COVID-19 ini (Indonesia.cochrane.org).

Nusa Tenggara Barat merupakan 
provinsi yang masuk dalam 10 besar pasien positif covid-19. Pada tanggal 27 April 2020 telah tercatat sebanyak 206 kasus positif covid19 yang tersebar di seluruh wilayah NTB termasuk kota Mataram dengan jumlah kasus yang paling banyak yakni 59 orang. Sebagai tanggapan terhadap pandemi ini, beberapa wilayah telah memberlakukan Pembatasan Sosial Berskala Besar (PSBB). NTB termasuk salah satu wilayah yang belum menerapkan PSBB.

Dengan belum diberlakukannya PSBB di wilayah NTB, masih banyak para warga terutama pekerja lepas seperti tukang ojek yang masih beroperasi di jalanan. Hal ini menjadi salah satu faktor risiko penularan covid-19 karena adanya kontak antara pengemudi dan penumpang.

Penularan covid-19 dapat melalui berbagai cara diantaranya yaitu tidak sengaja menghirup percikan ludah (droplet) yang keluar saat penderita covid-19 batuk atau bersin, memegang mulut dan hidung tanpa mencuci tangan terlebih dahulu setelah memegang benda yang terkena cipratan droplet penderita covid-19 atau kontak jarak dekat dengan penderita covid-19. Salah satu faktor risiko yang menyebabkan penularan covid-19 pada tukang ojek baik ojek online maupun offline adalah adanya kontak dalam jarak deka tantara penumpang yang mungkin positif covid-19 dengan pengemudi ojek itu sendiri.

Sebagian besar, masih terlihat pengemudi ojek yang tidak melengkapi dirinya dengan alat pelindung diri (APD) sebagai salah satu langkah pencegahan penularan covid-19. Minimnya pengetahuan dan kesadaran tentang bahaya covid-19 serta kurangnya pemasukan tiap harinya membuat para pengemudi ojek tidak menggunakan APD seperti masker.

Selain itu, juga tidak terlihat adanya tempat cuci tangan di sekitar tempat pengkolan. Hal tersebut bisa dikarenakan kurangnya fasilitas air bersih dan sanitasi di sekitar wilayah pengkolan sehingga para pengemudi ojek kesulitan untuk mencuci tangan setiap saat.

\section{METODE}

Kegiatan pengabdian ini dilaksanakan dengan beberapa tahapan diantaranya:

\section{a. Memproduksi handsanitizer dan masker kain}

Handsanitizer diproduksi secara mandiri di laboratorium Fakultas IImu Kesehatan, Universitas Muhammadiyah Mataram. Handsanitizer kemudian ditempatkan pada botol kemasan ukuran $30 \mathrm{ml}$ dan dilabeli menggunakan label yang telah didesain. Masker kain dipesan melalui penjahit lokal. b. Memetakan target yang akan diberi handsanitizer dan masker kain.

Setelah handsanitizer dan masker kain selesai diproduksi, tim pengabdian memetakan lokasi pengabdian dan target yang akan diberi handsanitizer dan masker kain. Lokasi target adalah sepanjang jalan Catur Warga dan Sriwijaya Kota Mataram karena di sepanjang jalan tersebut terdapat banyak sekumpulan pengemudi ojek.

\section{c. Membagikan handsanitizer dan} masker kain ke target pengabdian.

Pertama tim pengabdian meminta izin kepada sekumpulan pengemudi ojek untuk melakukan pembagian handsanitizer dan masker kain pada pengemudi ojek tersebut. Setelah itu handsanitizer dan masker kain. Kemudian pengambilan foto untuk dokumentasi.

\section{HASIL DAN PEMBAHASAN}

Kegiatan pengabdian ini dilaksanakan dengan beberapa tahapan diantaranya: Memproduksi handsanitizer dan masker kain. Handsanitizer adalah produk kesehatan yang secara instant membunuh kuman tanpa memanfaatkan air, dapat digunakan kapan saja dan dimana saja. Akan tetapi pemakaian alkohol pada kulit kurang aman karena alkohol merupakan pelarut organic yang dapat melarutkan sebum pada kulit, dimana sebum ini bertugas melindungi kulit dari mikroorganisme (Wijaya,2013).

Penggunaan handsanitizer lebih efektif dan efisien bila disbanding dengan menggunakan sabun dan air karena dapat membunuh kuman dalam waktu relative cepat, karena mengandung senyawa alkohol dengan konsentrasi $\pm 60 \%$ sampai $80 \%$ dan golongan fenol. Alkohol juga dapat mengakibatkan kekeringan dan iritasi pada pemakaian berulang terhadap kulit serta memiliki sifat mudah terbakar (Fatimah\&Ardiani, 2018).

Handsanitizer diproduksi secara mandiri di laboratorium Fakultas IImu Kesehatan, Universitas Muhammadiyah Mataram. Handsanitizer kemudian ditempatkan pada botol kemasan ukuran $30 \mathrm{ml}$ dan dilabeli menggunakan label yang telah didesain. Masker kain dipesan melalui penjahit lokal.

Masker terbuat dari bahan kain yang nyaman saat digunakan dan aman dari cipratan droplet, kain ringan tidak berat tidak suli tuntuk bernapas, bahan tali gampang digunakan untuk pemakai hijab. Sehingga upaya untuk melindungi paramedis dengan APD juga dapat diantisipasi (Kemenkes RI, 2020).

Memetakan target yang akan diberi handsanitizer dan masker kain. Setelah 
handsanitizer dan masker kain selesai diproduksi, tim pengabdian memetakan lokasi pengabdian dan target yang akan diberi handsanitizer dan masker kain. Lokasi target adalah sepanjang jalan Catur Warga dan Sriwijaya Kota Mataram karena di sepanjang jalan tersebut terdapat banyak sekumpulan pengemudi ojek.

Membagikan handsanitizer dan masker kain ke target pengabdian. Pertama tim pengabdian meminta izin kepada sekumpulan pengemudi ojek untuk melakukan pembagian handsanitizer dan masker kain pada pengemudi ojek tersebut. Setelah itu handsanitizer dan masker kain. Kemudian pengambilan foto untuk dokumentasi.

Banyaknya pengemudi ojek yang belum menggunakan masker dan tidak memiliki handsanitizer melebihi ketersediaan handsanitizer dan masker kain tim pengabdian. Selain itu, selain pengemudi ojek, terdapat beberapa orang yang meminta handsanitizer dan masker kain tim pengabdian.

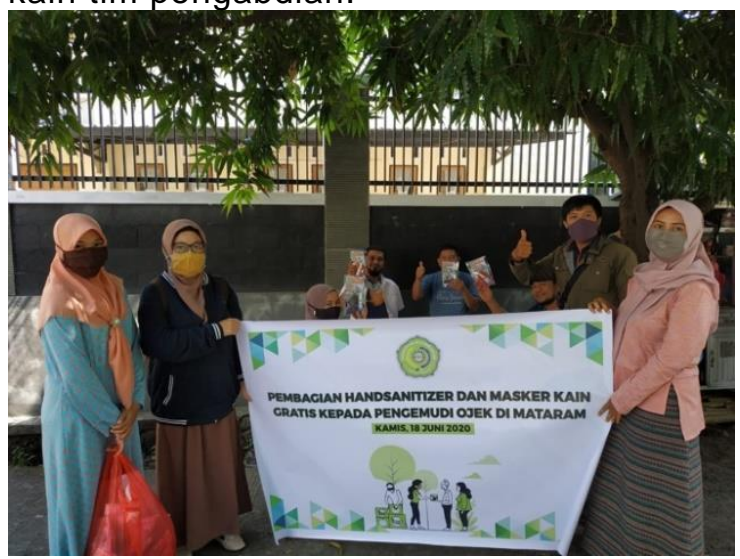

Gambar 1. Pembagian handsanitizer dan masker kain di jl. Caturwarga

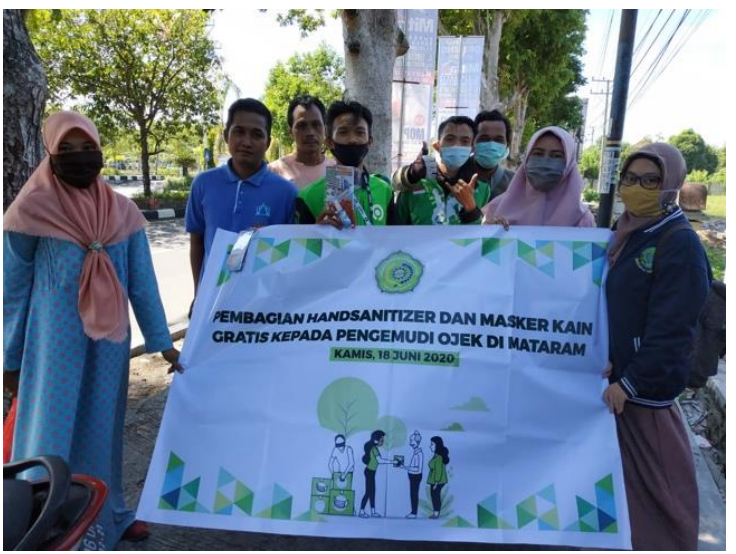

Gambar 2. Pembagian handsanitizer dan masker kain di jl. Sriwijaya

\section{SIMPULAN DAN SARAN}

Nusa Tenggara Barat merupakan provinsi yang masuk dalam 10 besar pasien positif covid-19. Salah satu faktor risiko yang menyebabkan penularan covid-19 pada tukang ojek baik ojek online maupun offline yang tidak menerapkan protokol perlindungan diri dengan baik. Tim pengabdian masyarakat membagikan handsanitizer dan masker kain kepada pengemudi ojek di Jl Catur warga dan Jl. Sriwijaya sebagai upaya pencegahan dan pemutusan rantai penularan Covid-19. Para pengemudi ojek sangat antusias menyambut pengabdian ini.

Pengabdian masyarakat dengan membagikan handsanitizer dan masker kain agar dapat diperluas tidak hanya di kota Mataram tetapi juga di beberapa kabupaten di Lombok.

\section{UCAPAN TERIMAKASIH}

Ucapan terimakasih diberikan kepada Lembaga Penelitian dan Pengabdian kepada Masyarakat (LPPM) Universitas Muhammadiyah Mataram yang telah mendanai kegiatan pengabdian ini sehingga kegiatan dapat berjalan dengan lancar. Terimkasih juga kepada semua tim pengabdian yang telah membantu dalam pelaksanaan kegiatan.

\section{DAFTAR RUJUKAN}

Fatimah, C., \& Ardiani, R. (2018). Pembuatan Hand Sanitizer ( Pembersih Tangan Tanpa Air ) Menggunakan Antiseptik Bahan Alami. Prosiding Seminar Nasional Hasil Pengabdian.

Foundation, I. (2020). Kawal informasi seputar COVID-19 secara tepat dan akurat. https://kawalcovid19.id/

Indonesia, C. (2020). COVID-19: Kumpulan Artikel IImiah. https://indonesia.cochrane.org/news/co vid-19-kumpulan-artikel-ilmiah

Pane, M. D. C. (2020). Virus Corona. https://www.alodokter.com/viruscorona

RI, Kemenkes. (2020). Pedoman pencegahan dan pengendalian corona virus disease (Covid-19). Germas.

RI, Kemnkes. (2020). Pedoman Kesiapsiagaan Menghadapi Corona virus Disease (COVID-19). Direkorat Jenderal Pencegahan Dan Pengendalian Penyakit.

Septia, K. (2020). Update Corona di NTB: Tambah 11 Pasien Positif, Total 206 Kasus.

https://regional.kompas.com/read/2020 /04/27/21162991/update-corona-dintb-tambah-11-pasien-positif-total-206kasus

WHO. (2020). Coronavirus disease (COVID-19) advice for the public. 
https://www.who.int/emergencies/disea ses/novel-coronavirus-2019/advice-forpublic

Wijaya, J. I. (2013). Formulasi Sediaan Gel Hand Sanitizer Dengan Bahan Aktif Triklosan 1,5\% Dan 2\%. Jurnal IImiah Mahasiswa Universitas Surabaya.

Wikipedia. (2020). Pandemi COVID-19 di Indonesia.

https://id.wikipedia.org/wiki/Pandemi_k oronavirus_di_Indonesia 